ReCaPe - Revista de Carreiras e Pessoas

\title{
THE USE OF CATEGORIES AS INDICATORS OF ORGANIZATIONAL CLIMATE IN BRAZILIAN COMPANIES
}

\author{
Joel Souza Dutra ${ }^{1}$ \\ André Luiz Fischer ${ }^{2}$ \\ Lina Eiko Nakata ${ }^{3}$ \\ Julio Cesar Rodrigues Pereira4 \\ Elza Fátima Rosa Velosos
}

\begin{abstract}
In order to analyze employees' perception of the work environment, companies with a well-established people management structure periodically conduct organizational climate surveys. These surveys are meant to offer an understanding of how employees view the quality of the relationships they experience in the company. One of the characteristics of this type of survey, identified both in the relevant literature and empirically in practice, is the use of categories or indicators to direct development of the research instrument, data analysis, and later intervention as needed according to the results of the survey. This article seeks to propose a categorization of organizational climate dimensions directed at the Brazilian corporate reality, analysing its internal consistency and its construct validity. To that end, we used the results of a wide-ranging data sample collected from 123,445 respondents of 491 organizations in various regions of Brazil. The proposed analysis categories - identity, satisfaction and motivation, learning and development, and leadership - were reviewed based on theories of organizational behavior and then submitted to a focus group composed of human resources professionals employed by prominent Brazilian corporations.
\end{abstract}

Artigo recebido em 14/01/2012

Aprovado em 21/03/2012

\footnotetext{
1 Professor na Universidade de São Paulo (FEA-USP), onde é responsável pelo grupo de estudos em gestão de carreiras. É também um dos coordenadores do Programa de Estudos em Gestão de Pessoas (PROGEP) da Faculdade FIA de Administração e Negócios, onde, entre outras funções, é responsável pelo método e pela coordenação geral da pesquisa As Melhores Empresas para Você Trabalhar no Brasil.

2 Professor na Universidade de São Paulo (FEA-USP), onde é responsável pelo grupo de estudos em gestão de pessoas. É também um dos coordenadores do Programa de Estudos em Gestão de Pessoas (PROGEP) da Faculdade FIA de Administração e Negócios, onde, entre outras funções, é responsável pelo método e pela coordenação geral da pesquisa As Melhores Empresas para Você Trabalhar no Brasil.

${ }^{3}$ Graduada, mestre e doutoranda em Administração pela Faculdade de Economia, Administração e Contabilidade da Universidade de São Paulo. É professora de graduação da ESAGS/FGV e pós-graduação da FIA e IPOG. Foi consultora do Great Place to Work Institute Brasil.

4 Docente Livre, Professor do Departamento de Epidemiologia da USP. Pesquisador CNPq 2 na área de Saúde Coletiva, Disciplinas de Epidemiologia e Gestão de C\&T.

5 Doutora em Administração pela FEA-USP. Atualmente é Coordenadora Executiva e professora na Faculdade FIA de Administração e Negócios, onde, entre outras funções, é responsável pela coordenação técnica da pesquisa As Melhores Empresas para Você Trabalhar no Brasil. É também professora na pós-graduação lato-sensu da Universidade Presbiteriana Mackenzie.
} 
Broken down into variables, each category was tested by a control question, included in the study questionnaire, and through statistical methods capable of indicating internal consistency (Cronbach's alpha). In doing so, we sought to prove the instrument's validity on four levels: theoretical, empirical, practical, and statistical. Among our conclusions, we may highlight the fact that construction of instruments must be guided by the search for practical utility to organizational management.

Keywords: Careers; work environment; organizational climate.

\section{INTRODUCTION}

Interest in organizational climate first surfaced in the 1930s, increased markedly with the advent of the Human Relations Movement, and has been the object of increasingly improved and specific studies over the past years. The literature provides several definitions for the concept of "organizational climate" or "environment", such as perceived organizational support (Eisenberger \& Huntington, 1986), the subjective structure of an organization (Payne \& Pugh, 1976) and the degree of similarity between the organization's expectations and those of its employees (Glick, 1985).

Schneider (2004), one of the main international references on the theme, claims that employees develop their perception from experience, which is based on how everyday business is conducted, rather than that what is said or made public by senior management or the content of official company documents. It is through concrete company initiatives, showing recognition and support, that employees form their perceptions and opinions of their importance to the company and to the work they do. For Schneider, the answer to the question "what matters here?" represents much of what has become known as organizational climate (Schneider \& White, 2004).

Concerned with gaining access to this internal "public opinion", companies with a wellestablished human resource management structure systematically conduct surveys on their work environment. These are meant to offer an understanding of the current state of relationships between the company and the people within it, not only with regard to satisfaction but also to understanding of company policies, agreement with strategic orientation, the quality of HR services, and other aspects.

A good example of the importance of these surveys can be found in a five-year forecast study meant to identify human resources policies to be introduced or maintained in Brazilian 
organizations. The study, carried out by the Delphi method on a panel of 160 HR professionals considered to be opinion leaders in the field, featured the use of organizational climate monitoring practices as one of the top five HR management priorities for the next few years. As can be seen in Table 1 below, 97\% of respondents considered these to be highly relevant management policy, $94 \%$ believed they would be introduced in coming years, and the degree of difficulty involved in their implementation was evaluated as being medium to high (score of 3,16 on a five-point scale).

Table 1

\begin{tabular}{|c|c|c|c|}
\hline Policies and Practices For Managing Human Resources & $\begin{array}{c}\text { Is } \\
\text { Relevant }\end{array}$ & $\begin{array}{c}\text { Will } \\
\text { Be } \\
\text { Introduced }\end{array}$ & $\begin{array}{c}\text { Degree } \\
\text { Of } \\
\text { Difficulty } \\
(1 \text { to } 5)\end{array}$ \\
\hline 1. Frequent feedback to employees on their performance & $100 \%$ & $94 \%$ & 3.45 \\
\hline 2. Intensive use of information technology in the self-learning process & $98 \%$ & $97 \%$ & 3.28 \\
\hline $\begin{array}{l}\text { 3. Emphasis on the biological, psychological and social needs of } \\
\text { employees (QVT) }\end{array}$ & $97 \%$ & $89 \%$ & 3.38 \\
\hline 4. Practices for continuously monitoring organizational climate & $97 \%$ & $94 \%$ & 3.16 \\
\hline 5. Partnerships with external institutions for development programs & $97 \%$ & $92 \%$ & 2.66 \\
\hline
\end{tabular}

Source: Fischer, A. L. \& Albuquerque, L. G. (2005). Trends of the human resources management model in Brazilian companies: a forecast according to opinion leaders from the area. International Journal of Human Resource Management, 16(7), 1211-1227.

Although surveys and management of organizational climate are relatively traditional practice, often considered by human resources professionals to have been mastered already, the content of such surveys and the manner in which they are conducted do not yet follow a single guideline. In fact, the use of corporate environment surveys is quite diversified among organizations, as are proposals by management scholars and people management consultancy companies. This diversity justifies further thought on the component elements of this type of diagnostic and the best way to operationalize them.

It is known that certain characteristics of the experiences people go through in an organization remain reasonably stable over time, which supports the adoption of standard content in surveys that seek to identify them. People who work will invariably come into contact with others, will be subjected to the power wielded by the organization and its leaders, will comply with established rules, and will get feedback on their behavior through various formal and informal reward and evaluation systems. However, the criteria used by agents to judge the quality 
of these relationships vary according to the specific circumstances of time and place (culture) in which they occur. One may therefore say that each party's expectations behind the psychological contracts of a present-day organization presume relationships - among people, with superiors, and with management policies - that are quite different from those found in companies during, say, the first half of the $20^{\text {th }}$ century.

We may therefore say that, as far as content is concerned, conducting an effective survey will depend on conceiving categories and variables that correspond to theoretically established, up-to-date validity criteria that meet the specific management demands of a given time. Of course, as required by good research practices, categories and variables must also be statistically sustainable and show consistency in that which they are meant to measure.

Although the need for validation of categories and variables used in measuring organizational climate is generally accepted by both scholars and HR professionals, its discussion is anything but common in current HR literature and in organizational practice. Organizational climate surveys and studies are usually conducted by private consultancy companies, which do not typically disclose or discuss the theoretical bases and methods underpinning the design of their data collection and analysis procedures. The proposed methods are also usually considered valid for any type of organization or nationality and, consequently, applicable to different countries and cultures without the need for any adaptation whatsoever.

The main objective of this article is to propose a categorization of organizational climate dimensions specifically directed at the Brazilian corporate reality, with supporting analysis of its internal consistency and construct validity. To this end, we used the results of a wide-ranging data sample collected in 2007 from 123,445 respondents of 491 organizations in various regions of Brazil. The proposed analysis categories - identity, satisfaction and motivation, learning and development, and leadership - were reviewed based on theories of organizational behavior and then submitted to a focus group composed of human resources professionals employed by prominent Brazilian corporations. Broken down into variables, each category was tested by a control question included in the study questionnaire and through statistical methods capable of indicating internal consistency (Cronbach's alpha).

The body of this article is divided into four sections. The first introduces a review of the literature on organizational climate and climate surveys, as well as the use of categories in them; the second section outlines our methods and a practical description of the present study; the third 
shows our validation of the proposed categories; and the fourth presents the results of our survey, followed by our conclusions.

\section{REVIEW OF THE LITERATURE}

\subsection{Evolution of the concept of organizational climate}

Lewin, Lippitt and White (1939) are credited with introducing the concepts of social climate and social atmosphere as interchangeable expressions to describe attitudes, feelings, and perceptions socially induced in individuals after a group experience (Schneider et al., 2001). In 1948, Lewin described his attempts at representing any given social process as part of a larger context or field, which he referred to as field theory (Ashkanasy et al., 2001). To Lewin, all behaviors, including action, thought, desire, pursuit, appreciation, and fulfillment, are conceived of as a change in some state of a field in a given unit of time (Lewin, 1951).

The emphasis on context highlighted by Lewin was closely related to the Gestalt psychology of perception that was concurrently being developed in American social psychology. It shows that human behavior does not result exclusively from individual will, but varies from the norm, and this variation is conditioned by the tension between self-perception and the psychological environment the person is part of (Ashkanasy et al., 2001).

Several contributions of the study of human attitudes in group environments became the reference on which the concept of organizational climate is consolidated. Ashkanasy highlights the role of Likert and the creation of his well-known and widely used scale for measuring attitudes in the development of organizational environment surveys. Likert's scale would have been one of the main advances responsible for the dissemination of organizational climate surveys that would begin in the 1960s in U.S. companies and research centers:

"Likert is best known for two things that helped define organizational climate research. One is the Likert scale for measuring attitudes, a technology that greatly increased the influence of attitude research throughout the social sciences. The other is the "System 4 view" of effective management." (Ashkanasy et al., 2001, p. 3)

One of the first studies labeled as being of organizational climate and focused on a specific organization was conducted by Argyris, in his 1958 case study "Some Problems in Conceptualizing Organizational Climate”. Argyris concluded that organizations must create an 
interpersonal atmosphere of trust, openness, and unthreatening. In a detailed historical review of the climate construct and its practice, Schneider (1990) notes that McGregor's classic "The Human Side of Enterprise" (1960) devoted a chapter to what its author called a "managerial climate".

The apparent consensus among experts in the field, however, is that the 1960s and 70s witnessed the real "explosion of research on organizational climate" (Schneider, 2000). It was the subject of countless studies and debates, and organizations made room for survey practices to be implemented. Specific aspects, such as the best definition of the organizational climate construct, its manifestation on the individual and group level, and differences between it and other areas of organizational behavior were meticulously and lengthily scrutinized. Some controversy would persist to the present day - such as the question of survey content (which we will deal with here), levels of analysis, and, most recently, the distinction between organizational climate and organizational culture -, but it did not prevent the 1960s and 1970s from being considered the golden age of scholarly output on the theme in the U.S. and Europe ("the magical 1960s"). Prominent experts on the theme, including Schneider himself, and practically every notable scholar of human behavior took part in the organizational climate debate: Litwin (1968), Lawler (1970), Kolb (1978), Schein (1975), and Pettigrew (1979).

In the 1990s, the concept appeared to be fully established, and its practice within organizations was reasonably well accepted, although no single, standardized way of making it operational had been instituted. Woodman \& King (1978), for instance, conceptualize organizational climate as the process of understanding individual behavior at the workplace itself. They claim their analysis is extremely valuable to Human Resources management, as the reality idealized by senior management may differ from that perceived by employees.

Although we agree with the above definition, we chose to adopt the broader concept formulated by Ashkanasy et al. for the purposes of this study. Through the adoption of certain ontological and epistemological assumptions beyond the scope of our study, they define organizational climate as follows:

"The concept of organizational climate is currently being used to describe configurations of attitudes and perceptions by organizations members that, in combination, reflect a substantial part of the context of which they work" (Ashkanasy, 2000) 
According to Schneider \& White (2004), certain conditions are required for this set of subjectivities to be created in a given organization, namely:

- $\quad$ Exposure of members to the same objective structural characteristics;

- Employee selection, retention, and task assignment practices and processes that produce a homogeneous membership in the organization;

- Social interactions that create a shared understanding between members.

Thus formulated, and once the conditions for its emergence were established, the concept of organizational climate fostered a new perspective in the business administration area: the search for arguments for the performance of human labor. The concept helped elucidate relevant organizational questions, particularly when related to other everyday aspects such as leadership, satisfaction, ethics, motivation, performance, and turnover. Although it is still questioned by a few researchers, assimilation of the organizational climate has been such that it is currently impossible to discuss organizational productivity, quality (Michela et al., 2000), strategy (Joyce et al., 1990), and performance without considering the environment to be an intervening variable (Oliveira, 1996).

\section{a. Organizational climate surveys}

Although many companies featuring well-structured HR management carry out organizational climate surveys, there is no consensus on their content, their objectives, and the manner in which this practice articulates with organizations' people management models (Fischer, 1996). There is general agreement that the study of organizational climate encompasses any type of quantitative study or survey of attitudes in organizations (Ashkanasy et al., 2000). Such studies therefore become entangled with other aspects of organizational life, such as satisfaction, motivation, organizational citizenship, ethics, culture, and others.

To some authors, such as Guion (1973), James \& Jones (1974), and Schneider \& Snyder (1975), this is nothing more than redundancy between similar themes. Fischer (1996) states that the objective of organizational climate surveys is broader, and consists of understanding the state of all relationships between the company and those involved with it. Satisfaction and motivation is one dimension of these relationships, but not the sole dimension. 
Therefore, one can conduct specific satisfaction and motivation surveys with simplified methods, or an organizational climate study that accounts for other factors as well, such as understanding of company policies and agreement with the organization's strategic orientation (Box 1).

Box 1 - Internal organizational surveys

\begin{tabular}{|c|c|c|}
\hline Type & Objectives & Status \\
\hline Satisfaction Survey & $\begin{array}{l}\text { To obtain information on the degree of } \\
\text { employee satisfaction with the } \\
\text { company, its actions, and its } \\
\text { representatives. }\end{array}$ & $\begin{array}{l}\text { Often conducted in companies, using } \\
\text { simple methods; rarely mentioned in } \\
\text { the literature. }\end{array}$ \\
\hline Motivation Survey & $\begin{array}{l}\text { Meant to identify the factors that } \\
\text { interfere with greater or lesser } \\
\text { employee motivation in the workplace. } \\
\text { Differs from satisfaction surveys with } \\
\text { regard to focus and content; this is } \\
\text { often noted by authors who distinguish } \\
\text { between the concepts of satisfaction } \\
\text { and motivation (Bergamini, 1997). }\end{array}$ & $\begin{array}{l}\text { Widely debated conceptually, but } \\
\text { rarely conducted. Attempts to identify } \\
\text { more subjective elements than } \\
\text { satisfaction surveys. It is usually } \\
\text { forward-looking, that is, to individuals' } \\
\text { inclinations regarding their future } \\
\text { attitudes towards the company. }\end{array}$ \\
\hline $\begin{array}{l}\text { Organizational } \\
\text { Climate Survey }\end{array}$ & $\begin{array}{l}\text { Seeks to understand the state of all } \\
\text { relationships between the company and } \\
\text { those involved with it, not only from a } \\
\text { satisfaction or motivation standpoint. } \\
\text { Studies aspects such as understanding } \\
\text { of company policies, agreement with } \\
\text { current strategic orientation, and others. }\end{array}$ & $\begin{array}{l}\text { Most popular concept, both in theory } \\
\text { and in practice; most companies with a } \\
\text { good HR structure conduct surveys } \\
\text { referred to as organizational climate } \\
\text { surveys, with little or no concern for } \\
\text { objectives. }\end{array}$ \\
\hline $\begin{array}{l}\text { Organizational } \\
\text { Culture Survey }\end{array}$ & $\begin{array}{l}\text { Designed to describe and analyze the } \\
\text { values and beliefs that guide } \\
\text { organizational behavior. It is linked to } \\
\text { the history of the subject group/sample } \\
\text { and the basic commonalities that link } \\
\text { its members. Usually observes less } \\
\text { conscious, subjective variables that } \\
\text { interfere with group members' } \\
\text { behavior. }\end{array}$ & $\begin{array}{l}\text { The organizational culture theory and } \\
\text { the practice of culture diagnostics have } \\
\text { become widespread over the past ten } \\
\text { years. Such surveys are, however, used } \\
\text { far less frequently in companies than } \\
\text { they are mentioned in the literature. } \\
\text { Organizational culture surveys require } \\
\text { highly sophisticated methods that are } \\
\text { controversial even in the areas that } \\
\text { originated them (anthropology, } \\
\text { psychology, and sociology). }\end{array}$ \\
\hline
\end{tabular}

Source: Fischer, 1996.

Organizational climate diagnostics are perceptual; they are therefore more intuitive than empirical. The persistence and dissemination of the climate concept in professional practice, as well as the possibility to relate it to other organizational variables, show the importance of more rigorous scholarly investigation of the subject (Oliveira, 1996).

Despite a proven relationship between organizational climate and corporate results ${ }^{1}$, the climate concept is a complex, multi-level phenomenon. Organizational climate surveys are theoretical 
and conceptual (Dedobbeleer \& Beland). However, the importance of empirical instruments in aiding the study of workplace conditions is well established.

\section{b. The use of categories in organizational climate surveys}

In this section, we will discuss the use of dimensions, categories, or content classification indicators in organizational climate surveys. We will refer to the classic literature on the theme and to articles recently published in major Brazilian journals and in Academy of Management (AoM) publications. So that our study could also encompass empirical information from the corporate sector, we also obtained data from the websites of the most prominent consultancy companies operating in Brazil and from business magazines that publish company rankings according to employee opinion of the quality of their workplace environment.

The traditional literature on organizational climate - already mentioned above - shows that some of its first authors classified variables or measurement factors when presenting their results. This allowed a more precise focus to be established for the analysis and evaluation of the phenomenon being researched.

Analytical categories feature, for instance, in seminal studies by Lewin (1948). It is widely known that Lewin always connected the psychosocial environment he studied to leadership categories. To Lewin, the social climate was not a highly complex theoretical category, and had no nuances or gray areas; leadership could be broken down into three broad qualifying categories: autocratic, democratic, and laissez-faire (Ashkanasy et al., 2001).

On the other hand, to Argyris (1960), understanding behavior within organizations requires the definition of two sets of variables representing diverse entities: the organization and the individual. The main objective of a survey is now to create generalizations and theories applicable to all organizations, from types defined for each empirical study case.

The work of Morse \& Reimer (1956), Likert (1961), and Katz \& Kahn (1966) prioritized the human context in organizations and its contribution to performance and organizational effectiveness; their analyses emphasized productivity results and human results. These authors upheld the idea that there is more to organizational performance than short-term productivity, and that employees' conditions in the workplace (atmosphere and climate) can have significant consequences (Ashkanasy et al., 2001). Organizational climate considers some dimensions, 
because the perceptions about the workplace can be global or specific (Schneider \& Snyder, 1975).

\section{Review of scientific publications}

A search of the annals of all events promoted over the past ten years by ANPAD (Associação Nacional de Pós-Graduação e Pesquisa em Administração), the foremost Brazilian management association, and all Academy of Management (AoM) publications, also over the past ten years, as well as the Revista de Administração Contemporânea (RAC, a prominent Brazilian journal published by ANPAD), revealed a dearth of articles on organizational climate and, particularly, on the use of categories in evaluating climate. We found no articles published during the search period that focused on the variables, factors, dimensions, or evaluation categories used in organizational climate surveys. In fact, not a single article having organizational climate as its main theme was found in back issues of the $R A C$ or in AoM publications $^{2}$.

A review of annual meetings promoted by ANPAD over the past five years identified six articles that deal with organizational climate surveys and use content categories, although none discusses the theme in depth. Three of the six reported on surveys that employed a methodology devised by Embrapa (Empresa Brasileira de Pesquisa Agropecuária), which accounts for four dimensions: occupational, organizational, psychosocial, and extra-organizational. The case companies were Banco do Brasil, organizations in the tourism sector, and those in the technological innovation sector; the tourism survey adopted only two of the four original dimensions.

The fourth article discussed the results of a survey taken by faculty of the Federal University of Paraíba (UFPB), dealing with both organizational climate and culture. The dimension and content decisions of the survey were based on Kolb (1978) and Quinn (1988), and defined the following indicators: leadership, support, recognition, responsibility, clarity, conformity, standards and rewards.

The fifth study concerned a survey on organizational climate and stress in the workplace, conducted in a company in the Brazilian electrical sector. It employed four dimensions employee appreciation, relationship environment, support from management, and communication. The authors claim the dimensions were validated by the OCS (Organizational 
Climate Scale) method. The sixth and final article identified by our review deals with the intersection between organizational climate and organizational commitment. The questionnaire was applied to companies in several sectors, and constructed according to the Coda's methodology, which encompasses the following categories: nature of job, identification with employer, style/ quality of leadership, relationship with the workplace, relationship with the community, career perspectives, communication process, recognition displayed, interdivisional relationship, management philosophy, and HR policy (Leitão, Guimarães \& Rosal, 1998; Oliveira \& Moraes, 1999; Tamayo, Lima \& Silva, 2002; Sá, Mendes, Bispo, Telmo, Lacerda \& Alves, 2006; Santos \& Bedani, 2004; Nascimento, Candatten \& Maciel, 2004).

\section{Study of consultancy companies operating in the Brazilian market}

In order to identify the use of categories in organizational climate surveys conducted in Brazilian companies, we looked to service providers in the HR sector. Initially, we informally questioned HR professionals from prominent organizations, and requested that they point us toward HR consultancy companies considered relevant in the Brazilian market. Once these companies had been identified and chosen, we visited their websites in search of their survey categories. As none of the websites provided this information, companies were directly contacted by email; none, however, replied to our requests within 30 days.

From this survey of HR service providers in the Brazilian market, we conclude that, although it is common knowledge that several such companies provide organizational climate diagnostics, only one publicly discloses the categories used in its surveys - a U.S. company that conducts yearly studies and compiles rankings of organizations according to the quality of their work environment. The categories adopted in these studies were developed by journalist Robert Levering, who took an interest in the theme after carrying one such survey commissioned and published by Fortune magazine. His proposed methods appear to be based not on any of the earlier literature on the theme, but on the author's own experience (Levering, 1986), and consists of the following analytical categories: credibility, respect, fairness, pride, and camaraderie.

After reviewing the national and international literature and surveying HR service providers, we focused on proposing relevant categories for assessing the quality of a workplace environment. Our proposal, which will be presented and discussed throughout this article, was built on an 
empirical basis - ten years of experience conducting organizational climate surveys in major Brazilian companies -, enriched by and reformulated according to the findings of our review of the literature.

\section{c. Proposed Organizational Climate Categories or Dimensions}

Our survey categories (identity; satisfaction and motivation; learning and development; and leadership) were devised based on the assumption that individuals form their opinions of organizational climate from their perception of the quality of their workplace relationship experiences. These relationships are preceded by expectations built by organizational agents; whether they are met or not, these expectations give way to perceptions that consolidate and are validated by the group as truths of the reality of working in that particular company.

The impact of these perceptions on behavior creates cognitive states that, though subjective, can be objectively measured (Schneider et al., 2000). Figure 1 was designed to represent this model of analysis.

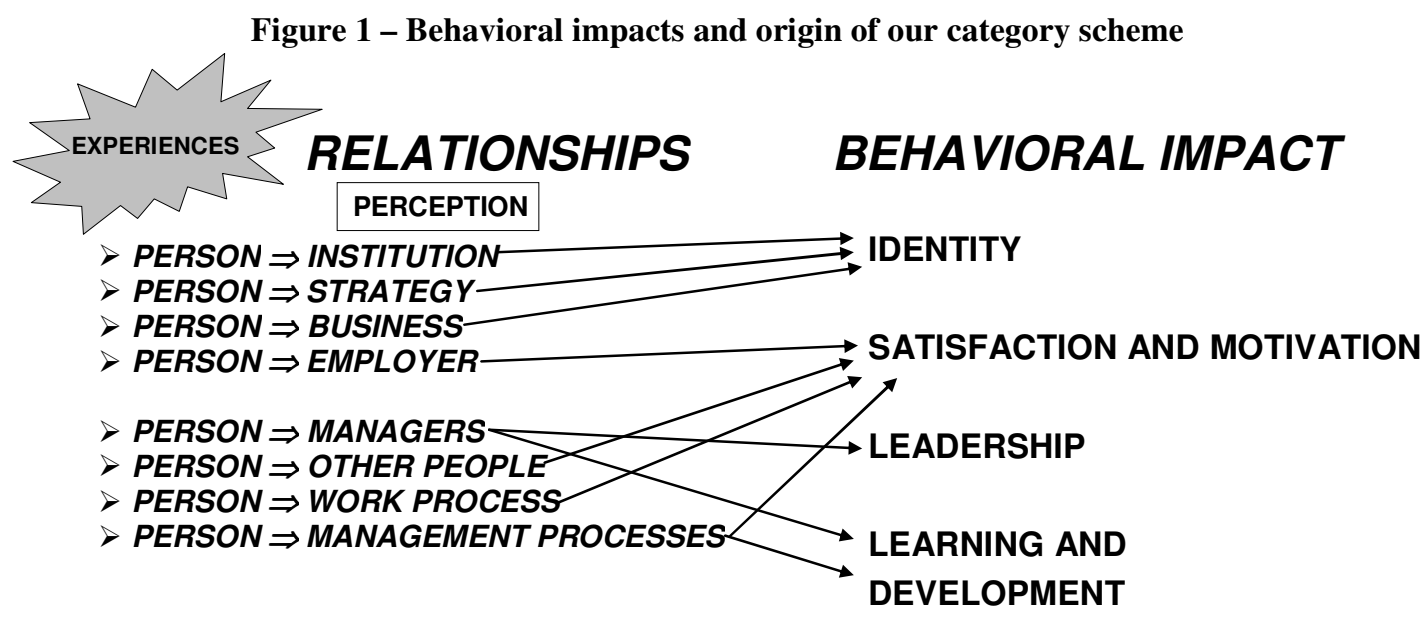

Source: Devised by authors.

\section{Model for Establishing Analysis Categories}

The above cognitive states, turned into analysis categories, are quite traditional and wellknown in organizational literature. We will discuss them below; we do not, however, intend to exhaust each theme, as the relevant external literature is extensive and diverse. 


\section{PUC-SP}

\subsubsection{Identity}

For the purposes of this study, we consider one of the components of the organizational climate construct to be the extent to which employees relate to, or identify with, the company. We will refer to this dimension as identity; it reveals employees' perception of the company as an entity within their reference social context. This indicator comprises the pride of "belonging" and the satisfaction obtained in referring to one's employer.

The basic social sciences have long recognized the importance of the feeling of identity as one of the basic principles of sociability, and a part of the human being's nature as a social being. Both social psychology and sociology, whether or not applied to the workplace environment, reaffirm this statement.

Contemporary philosophers such as Bauman (2005) view the longing for identification as stemming for the need for security - security that comes with belonging to a certain reference group, which, in the so-called postmodern world, is less and less matched by reality. (Giddens, 2002).

In demonstrating the importance of identification in the workplace, Beyer et al. (2000) state:

"Like other social identification, identification with an organization (Ashforth \& Mael, 1989) results from individuals' categorizing themselves as members of organizational groups and internalizing these social categories or memberships." (Taijfel \& Turner, 1985).

Beyer et al. also propose a definition of organizational identity quite similar to the one sought by this study: “...strength of [a] person's identification with an organization reflects the extent to which that person's self-concept includes the same characteristics he or she perceives to be distinctive, central and enduring to the organization". (Beyer et al. 2000, p. 333)

The identity category of behavioral impact comprises the data concerning the level of employee integration to the company and its strategy, that is, how much employees believe the company corresponds to their personal values and to the manner in which they think and act.

\subsubsection{Satisfaction and Motivation}

Reichers \& Schneider (1990) assign a great deal of importance to the shared perception of the way things are around here, that is, just how satisfied people are with that which is part of 
their daily life. The respondent's satisfaction with his or her job, interpersonal relationships, and employer's management policies and practices has always been the key element of environmental diagnostics.

With the emergence of the Human Relations Movement, motivation starts becoming the dominant element of the ideal workplace (Fischer, 1996). As Bergamini (1997) states, motivational factors differ from those that determine satisfaction in the workplace. More recent approaches show how these factors depend on the characteristics of individuals and the groups they belong to. According to this perspective, people are stimulated by different motivational factors and, as well as seeking distinct modes of satisfaction, have different contributions to make to the organization (Casado, 2002).

The satisfaction and motivation category groups the opinions of people on the relationships they experience in the workplace and the rewards these experiences bring. One's job description (what they do and how they do it), the company's physical environment (safety, equipment etc.), management processes (including HR management), rewards (type of compensation and how it is received), and social environment (what one relates to and how) fall into this category.

\subsubsection{Leadership}

Leadership is a social process in which relationships of influence are established among people (Limongi-França \& Arellano, 2002). The leader plays several roles, such as developing competencies in his or her team, being a facilitator and mentor where required and training and creating new leaders. The leader's performance depends on sharing results with others (Levek \& Malschitzky, 2006). Leadership also plays a distinct role in organizational climate, as leaders are the ones responsible for its management.

Some authors go as far as claiming that the leader is capable of single-handedly defining the quality of an organizational environment. Rogers (1961), for instance, states that a team becomes more responsible, creative, cooperative, and adapts more easily to new challenges and problems when its manager creates environmental conditions conducive to these processes. According to Schein (1989), leaders' judgment, motivation, and communication skills convey a feeling of commitment to the group. It is therefore recognized that leadership can effect a 
cognitive redefinition in those led, setting into motion and even producing new visions and concepts, as long as leaders hone their ability to create a sense of engagement and participation. The leadership category of behavioral impact comprises the following factors: employees' degree of trust in their superiors, and the credibility superiors inspire in their subordinates; perception that leaders act in a guidance-providing, inspirational, and balanced or "balancing" manner (promoting fairness).

\subsubsection{Learning and Development}

Several authors highlight the need for contemporary organizations to create environments conducive to learning (Senge, 1990; Garvin, 1993; Nonaka \& Takeuchi, 1997). Such organizations provide a morally gratifying environment, in which people can develop specialized knowledge while also developing their virtues (Arruda, Whitaker \& Ramos, 2001). According to Eboli (2002), it is of the utmost importance that corporate education and training and development practices foster personality-infused behavior in the workplace, providing conditions for the development of creative knowledge in not only the classroom but also everywhere business is conducted.

A mindset directed at continuous learning and self-development is a state of mind that is increasingly present in modern-day professionals. From the moment these people enter the work environment, they seek a process of constant growth that will help them become stronger individuals as well as more competent professionals; however, it is essential that organizations provide conditions that make this a reality as well as an expectation.

The learning and development category is defined by one's sense of intellectual, personal, and professional growth within one's employer. It involves factors such as the feeling one is learning in the workplace, (Garvin, 1993), sharing, willingness to help (Krogh et al., 2001), participation (Nonaka \& Takeuchi, 1995), appreciation showed by the company towards corporate education activities (Meister, 1999), and career advancement opportunities (Dutra, 2004).

These categories, once described and defined as above, were subjected to several tests of internal consistency and validity. The following sections will discuss the methods employed for testing and the results obtained. 


\section{STUDY METHODS, CONSTRUCTIONS AND CONDUCTION}

This section will outline the main characteristics of the study conducted in order to analyze the consistency of our proposed category scheme. We will discuss a few methodological bases, the procedures we used to define each category's set of component variables, the testing and construction stages of our survey instrument, the strategy used in conducting the survey proper, and respondent's characteristics.

\subsection{METHODS AND FRAMEWORK OF ORGANIZATIONAL CLIMATE CATEGORIES OF DIMENSIONS}

\subsubsection{Survey Type and Instrument Adopted}

This study adopts the most common research method used in organizational climate diagnostics, the opinion survey. It is a quantitative method (Easterby-Smith, 1991) considered adequate for attitude and opinion studies, as is the case of studies on perception of one's work environment.

Selttiz et al. (1987) state that the survey is meant to study phenomena that influence interactions among people in everyday life. Therefore, data must be collected from all or much of a study population, in order to evaluate the relative incidence, distribution, and interrelatedness of the study phenomena (Kerlinger, 1964).

The survey instrument must be devised so as to detect attitudes that, according to Richardson et al. (1999), are predispositions to negative or positive reactions towards certain objects, institutions, concepts, or people. To these authors, the use of scales creates adequate instruments for the measurement of attitudes; they recommend that the researcher formulate a series of items based on manifestations that supposedly correlate with the attitude to be studied, and this was the procedure adopted in our survey. We devised alternatives to be used in our questionnaire that corresponded to respondents' possible attitudes towards experiences in the workplace. In measuring, we adopted Likert's scale of agreement, from one to five. As all of our alternatives denoted a semantically positive quality to the theme under consideration, we labeled the scale from "disagree completely" (1) to "agree completely" (5) (Gil, 1999). 


\subsubsection{Construction of the research instrument}

Design of the questionnaire's alternatives was based on a database of over 200 variables used in organizational climate surveys, compiled by the authors over a ten-year period of academic and professional experience. Out of these variables, we chose and adapted 64 that would make up the final instrument used in our survey. Our criteria for valuable selection were: (1) a semantic correspondence with the category description and (2) limited number of total variables and variables per category.

Semantic correspondence to category descriptions was evaluated by experienced professors of Human Resources-related departments and later submitted to a group of HR professionals for further validation. The maximum number of variables in the questionnaire was based on the maximum time limit set for the questionnaire after filling it in ourselves. In order to maintain response quality, we found a twenty-minute limit reasonable for a respondent with elementary-level formal education. Pre-tests conducted to validate these criteria set a maximum questionnaire size of 64 statements.

Distribution of variables among the defined categories was proposed by the authors and submitted to a group of HR professionals employed by prominent organizations during a workshop held solely for this purpose. Over the course of their activity, the group found that the questionnaire should be constructed according to the following distribution of variables among the proposed categories:

Table 2 - Percent of statements composing comprised in each study category

\begin{tabular}{|l|c|c|}
\hline \multirow{2}{*}{ CATEGORY } & \multicolumn{2}{|c|}{ STATEMENTS } \\
\cline { 2 - 3 } & $\mathbf{n}$ & $\mathbf{( \% )}$ \\
\hline Identity & $\mathbf{0 9}$ & $\mathbf{1 4 . 1 \%}$ \\
\hline Satisfaction and Motivation & $\mathbf{3 0}$ & $\mathbf{4 6 . 9 \%}$ \\
\hline Leadership & $\mathbf{1 5}$ & $\mathbf{2 3 . 4 \%}$ \\
\hline Learning and Development & $\mathbf{1 0}$ & $\mathbf{1 5 . 6 \%}$ \\
\hline \hline TOTAL & $\mathbf{6 4}$ & $\mathbf{1 0 0 \%}$ \\
\hline
\end{tabular}

Source: Compiled by authors.

Complying with the above criteria, the final questionnaire contained 64 statements, each of which could be answered with one of alternatives in the following scale: (1) Disagree 
completely; (2) Mostly disagree; (3) Neither agree nor disagree; (4) Mostly agree; (5) Agree completel; or (DK/NA) Don't know or not willing to answer.

In order to validate construction of the categories and their adequacy to the Brazilian reality, we introduced the following general question in the instrument: What makes you consider a company an excellent place to work? This question preceded the 64 statements and accepted only one answer; the respondents' alternatives were each of the proposed organizational climate categories we defined, each followed by a description of its meaning, and a "none of the above" alternative, which gave respondents the possibility to disagree with the proposed categories and describe, in their own words, their opinion of what makes a company "a good place to work". When choosing "none of the above", respondents were prompted to describe their position on the theme in the form of an open-ended question.

The following table illustrates the manner in which the general question was applied and the study category to which each alternative corresponded:

Table 3 - General question and answer alternatives

\begin{tabular}{|c|c|}
\hline \multicolumn{2}{|l|}{ What makes you consider a company an excellent place to work? } \\
\hline Alternative & Corresponding category \\
\hline $\begin{array}{l}\text { Understanding and agreeing with the company's goals, what the } \\
\text { company does for its clients, and what it offers to the society and to the } \\
\text { community. }\end{array}$ & Identity \\
\hline $\begin{array}{l}\text { Being satisfied and motivated with what I do, what I earn, and my day- } \\
\text { to-day work routine. }\end{array}$ & Satisfaction and motivation \\
\hline $\begin{array}{l}\text { Realizing that I am learning more and more at the company and that it } \\
\text { gives me the opportunity to grow both as a professional and as a person. }\end{array}$ & Learning and development \\
\hline $\begin{array}{l}\text { Having bosses I respect, trust, and who provide their team with adequate } \\
\text { guidance. }\end{array}$ & Leadership \\
\hline None of the reasons described above. & None (open-ended question) \\
\hline
\end{tabular}
Source: Devised by authors.

Both the general question - our control as to the validity of the proposed categories - and the 64 statements that followed were pre-tested on 30 employees of a standard organization. Results suggested a need for adjustments, but confirmed the face value of the proposed alternatives. After pre-testing, in order to qualitatively validate our category scheme, we conducted three meetings (between 2005 and 2006) with the top HR executives of prominent companies operating in the Brazilian market ${ }^{3}$ and with professors of Human Resources Management from the faculty of a prominent national business school. 


\subsubsection{Survey conduction, participating companies, and respondents}

Three criteria were established for participation in the survey, all related to the respondent's employer:

- $\quad$ The company had to employ over 100 staff at the time of the survey (2007);

- $\quad$ The company had to have been operating in Brazil for over five years;

- The company had to be willing to take part in the survey and willing to comply with rules for random respondent sampling.

All Brazilian organizations meeting the above conditions were invited to take part by means of a tombstone ad published in a major periodical directed at the corporate sector. Ultimately, 491 companies took part in the study, for a total of 123,445 respondents. Company size varied greatly, from the minimum 100 staff to one participant that employed 107,595 people. The average number of employees was 3,168; the median was 688 .

The participant organizations were found to belong to highly diverse sectors. The survey had respondents employed by: corporations operating in food, beverages, and tobacco; wholesalers; foreign trade companies; the automotive sector; banks; retailers; and others.

To ensure a certain randomness in sampling, we requested that the participant companies send in a numbered, alphabetized list of all employees, from which we drew those who were to receive the questionnaire (through numerical codes assigned to each listed employee, corresponding to their name). All those selected were formally and legally employed by a participant company. Interns, temporary workers, and those not having the participant company as their sole employer were excluded from the study.

The data below presents a sintetic profile of the respondents' population researched:

- Sex: $68 \%$ masculine, and $32 \%$ feminine;

- Position: $35 \%$ in operational functions, $18 \%$ of technicians, $16 \%$ in administrative work, $9 \%$ of vendors, $8 \%$ of supervisors, $7 \%$ of managers, $1 \%$ of directors, and $6 \%$ others;

- Age: 33 years old, in average;

- Work time: seven years in the company, in average;

- Education: $34 \%$ of the sample had complete superior level or post-graduate course. 


\section{DESCRIPTION AND ANALYSIS OF RESULTS}

As mentioned at the beginning of the article, the purpose of this study is to analyze the use of categories for organizational climate variables in Brazilian companies. We adopted three distinct validation strategies for our study, one of them qualitative - (1) a focus group of experts in the field - and the remaining two, quantitative in nature: (2) a control question and (3) consistency analysis.

For the first stage of validation, we subjected the categories and their component variables to a focus group of professionals from prominent HR companies operating in the Brazilian market and scholars from the HR management field. We promoted group dynamics for debate and consensus building, seeking validation of the categories and a defined allocation of our variables. The results of this procedure, described in detail in a separate specific paper, were wholly favorable to the original category scheme and suggested minor reformulation of the variables' content.

The results of the control question included in the questionnaire are shown in the following table:

Table 4 - Breakdown of answers to the general question What makes you consider a company an excellent

\begin{tabular}{|c|c|c|}
\hline CATEGORY & DESCRIPTION OF CATEGORY MEANING & $(\%)$ \\
\hline $\begin{array}{l}\text { Learning and } \\
\text { development }\end{array}$ & $\begin{array}{l}\text { Understanding and agreeing with the company's goals, what the } \\
\text { company does for its clients, and what it offers to society and to the } \\
\text { community. }\end{array}$ & $38.8 \%$ \\
\hline $\begin{array}{l}\text { Satisfaction and } \\
\text { motivation }\end{array}$ & $\begin{array}{l}\text { Being satisfied and motivated with what I do, what I earn, and my } \\
\text { day-to-day work routine. }\end{array}$ & $34.3 \%$ \\
\hline Identification & $\begin{array}{l}\text { Realizing that I am learning more and more at the company and } \\
\text { that it gives me the opportunity to grow both as a professional and } \\
\text { as a person. }\end{array}$ & $20.3 \%$ \\
\hline Leadership & $\begin{array}{l}\text { Having bosses I respect, trust, and who provide their team with } \\
\text { adequate guidance. }\end{array}$ & $4.8 \%$ \\
\hline $\begin{array}{l}\text { None of the above } \\
\text { reasons }\end{array}$ & $\begin{array}{l}\text { Please describe what makes you consider a company an excellent } \\
\text { place to work. }\end{array}$ & $1.8 \%$ \\
\hline
\end{tabular}

Source: survey conducted by authors $(n=123,445)$.

Analysis of the categories' external validation, based on the control question, shows that over $98 \%$ of respondents chose one of the proposed categories, and only $1.8 \%$ believed other qualities characterize a company as an excellent place to work. The magnitude of this difference - between those who adjusted to the categories and those who found other possibilities to define a good organizational climate - alone would render more specific statistical testing of the data or stricter investigation of responses unnecessary. However, to lend further validity to our category 
scheme, we carried out qualitative analysis of the descriptions provided by respondents who chose the open-ended alternative "None of the above".

Analysis of the content of these descriptions showed no regular pattern that would warrant the creation of another category or adaptation of the existing ones. In most cases, respondents choosing the open-ended alternative nonetheless left the space where they were to provide an answer in their own words blank, or repeated, with distinct wording, a description similar to one of the four proposed dimensions.

It is beyond the scope of this article to discuss the purported reasons that distinguished respondents' opinions from the proposed categories, or the frequency of alternate answers. It is worth noting, however, that a sense of learning and development within the company was the leading characteristic of a good workplace environment in our sample's view. This may be attributed to the characteristics of the participant companies; most were large, well-structured corporations concerned with preserving their image in the market, and it is reasonable to assume that such companies attract those interested in learning and in possibilities of personal and professional development.

The satisfaction and motivation category, which came in second in our respondents' perception of a good organizational climate, shows that compensation (including salary and benefits), accomplishment and actualization in the workplace, and the quality of the physical and social work environment still prevail in the mindset of a significant share of Brazilian workers. The high percentage of respondents choosing this alternative (34.3\%) also shows that the focus groups' decision of assigning significant weight to this category when allocating statements in the questionnaire was highly coherent.

The relevance of a company's value to society is reflected in the percentage of respondents choosing the identity category (20.3\%). An employee's ability to relate to the organization's values, goals, and strategies certainly determines their commitment to the company, and it seems to be of the utmost importance to one-fifth of respondents is considering whether or not an organization could be an excellent place to work.

The low percentage of respondents choosing the leadership category in determining whether a company's environment is good warrants in-depth study, for which the data we obtained is insufficient. Two hypotheses may be proposed: either bosses have been losing their 
place as those most responsible for maintaining a company's organizational climate - due to rotation among different company departments, early promotions or rapid career advancement etc. - or leaders are seen much more as the product or result of the other three categories. In the latter case, leaders would be the result of the organization's values and practices, would be limited by company policies of worker recognition and workplace management, and their actions would be conditional to the processes that lead to learning and development. In any case, the above hypotheses amount to no more than speculation on our part, nonetheless worthy of scrutiny and in-depth investigations seeking their elucidation; what bears noting is that respondents provided no consistent, regular, or frequent alternatives to the proposed categories, which seems a good indicator of their validity.

The third validation strategy consisted of a statistical study of internal consistency for the proposed categories. Initially, we calculated Cronbach's alpha - a statistical indicator known for its capacity to measure the consistency of a research dimension - for each category. Cronbach's alpha was then calculated for the proposed set of categories as a whole. The intended purpose of this strategy was to verify whether the four proposed categories (identification, satisfaction and motivation, learning and development, and leadership) came together as a consistent indicator of organizational climate.

Data were processed with the SPSS statistical software package, and the following results were obtained:

Table 5 - The four categories and their reliability statistics

\begin{tabular}{|l|c|c|}
\hline \multicolumn{1}{|c|}{ CATEGORY } & Cronbach's Alpha & N. of Items \\
\hline Identity & 0.902 & 9 \\
\hline Satisfaction and Motivation & 0.963 & 30 \\
\hline Learning and Development & 0.912 & 10 \\
\hline Leadership & 0.960 & 15 \\
\hline
\end{tabular}

In analyzing the above data, it is important to consider that Cronbach's alpha represents consistency between the component variables of an indicator. Its value ranges from 0 (zero): no consistency and components appear to vary in different directions, not reliably composing a category or indicator; and 1 (one): all components appear to vary consistently in one direction, suggesting a specific dimension of the object or phenomenon being studied (Pereira, 2001). When the coefficient alpha levels are above 0.70, it shows that each of the leader characteristics 
and behaviors correlates positively and significantly, according to the criteria established (Mitchell, 1985).

We note that Cronbach's alphas calculated for each proposed category were significantly elevated, which suggests high consistency between each category's component variables. The variables chosen to measure respondents' opinion in each category therefore appear to be indicators pointing to a same direction. This phenomenon was also found in some papers. As examples, it is possible to cite: Bacharach and Bamberger's study about traumatic work-related events, Detert and Burris' investigation about leadership behavior and employee voice, and a research about job performance made by Hunter and Thatcher, all published in The Academy of Management Journal in 2007.

Results obtained through calculation of Cronbach's alpha are complemented by the itemtotal statistics, which analyze each component item or variable of a category, showing variation of the indicator's consistency upon deletion of each of its components. Due to article length concerns, we will not publish all our item-total statistics; as an example, we include the following table, which presents statistics for the Identity category.

Table 6 - Item-Total Statistics: Identity category

\begin{tabular}{|l|l|r|r|}
\hline Var & \multicolumn{1}{|c|}{ Abridged Description } & \multicolumn{1}{|c|}{$\begin{array}{c}\text { Corrected Item- } \\
\text { Total Correlation }\end{array}$} & $\begin{array}{c}\text { Cronbach's Alpha } \\
\text { if Item Deleted }\end{array}$ \\
\hline Q1 & I would recommend this company to family or friends & 0.687 & 0.890 \\
\hline Q23 & $\begin{array}{l}\text { The company contributes positively to the community } \\
\text { and to the environment }\end{array}$ & 0.636 & 0.894 \\
\hline Q25 & I am proud to say I work for this company & 0.739 & 0.887 \\
\hline Q31 & $\begin{array}{l}\text { The company provides unbiased attention to employees, } \\
\text { shareholders, and suppliers }\end{array}$ & 0.740 & 0.886 \\
\hline Q33 & The company delivers what it promises to clients & 0.665 & 0.892 \\
\hline Q34 & I take part in decisions that affect my work routine & 0.632 & 0.896 \\
\hline Q44 & $\begin{array}{l}\text { People know what to do to make this company a better } \\
\text { place }\end{array}$ & 0.695 & 0.890 \\
\hline Q53 & I know and agree with the company's objectives & 0.712 & 0.888 \\
\hline Q57 & $\begin{array}{l}\text { The company's products and services are important to } \\
\text { the society }\end{array}$ & 0.574 & 0.898 \\
\hline
\end{tabular}

The Identity category is composed of nine variables, represented in the first column on the left by statements coded from Q1 to Q57; the statements themselves are described in the second column from the left. The main results that can be observed from the above data are in the last 
column - Cronbach's alpha values for the category if a given variable is deleted. Since the original alpha for the category was 0.902 , it is apparent that the deletion of any variable would cause a decrease in Cronbach's alpha for the category, that is, deletion of any item would make the category less consistent as a whole.

Variable Q31 warrants special attention. It showed the highest item-total correlation with the corrected indicator, and would cause the most significant decrease in category consistency (to 0.886) if deleted from the survey. It bears noting that a qualitative analysis of this variable's semantic meaning reveals its characteristically generic content: provides unbiased attention to employees, shareholders, and suppliers. This variable therefore identifies an organization with egalitarian values, which, when displayed in a for-profit corporation, are highly regarded by society.

Again, item-total statistics for the remaining three categories will not be presented due to space constraints, but their analysis revealed the following highlights:

- In the Satisfaction and Motivation category, which had a Cronbach's alpha of 0.963, deletion of any item would bring alpha no higher than 0.962 .

- In the Learning and Development category, which had a Cronbach's alpha of 0.912, deletion of any item would bring alpha no higher than 0.905 .

- In the Leadership category, which had a Cronbach's alpha of 0.960, deletion of any item would bring alpha no higher than 0.959 .

Also using Cronbach's alpha, we sought to measure whether the four proposed organizational climate categories (identification, satisfaction and motivation, learning and development, leadership) could be considered consistent as a set. The authors propose that this joint measurement represents the organizational climate of a company or group of companies. The results are described below:

Table 7 - Reliability Statistics: Category Set as a Whole

\begin{tabular}{|c|c|c|}
\hline Cronbach's Alpha & Cronbach's Alpha Based on Standardized Items & $\mathbf{N}^{\mathbf{0}}$ of Items \\
\hline 0.947 & 0.951 & 4 \\
\hline
\end{tabular}


Table 8 - Item-Total Statistics

\begin{tabular}{|l|r|r|r|}
\hline \multicolumn{1}{|c|}{ Category } & $\begin{array}{c}\text { Corrected Item- } \\
\text { Total Correlation }\end{array}$ & $\begin{array}{c}\text { Squared Multiple } \\
\text { Correlation }\end{array}$ & $\begin{array}{c}\text { Cronbach's Alpha } \\
\text { if Item Deleted }\end{array}$ \\
\hline Identity & 0.857 & 0.799 & 0.938 \\
\hline Satisfaction and Motivation & 0.929 & 0.881 & 0.916 \\
\hline Learning and Development & 0.892 & 0.807 & 0.926 \\
\hline Leadership & 0.840 & 0.721 & 0.944 \\
\hline
\end{tabular}

Once again, we found Cronbach's alpha to be very elevated for the categories as a set: 0.947 , suggesting that they combine consistently with one another. Item-total analysis shows that no category can be deleted without compromising overall consistency. The category that contributes most to general organizational climate appears to be Satisfaction and Motivation: item-total correlation, $\mathrm{r}=0.929$ and deletion would result in Cronbach's alpha dropping to 0.916. Leadership was found to contribute the least to general climate, but its deletion would still cause a minute decrease in consistency for the set.

In short, our results show that each analysis of the proposed categories confirmed their internal consistency, both as separate entities and as a set meant to be used as an indicator of organizational climate.

\section{FINAL CONSIDERATIONS}

Validation of the content of an organizational climate survey can never truly be considered complete at any moment in the theory's evolution; it is a constantly moving theoretical and methodological target. Several authors have shown that the internal dimensions of this type of survey must be pursued indefinitely, but cannot ever be considered absolute or definitive.

Schneider found that factor analysis studies produced varying numbers of dimensions (two to nine), which resulted in the use of different scales for measuring organizational (Schneider \& Bartlett, 1968; Schneider \& Hall, 1972; Lawler et al., 1974; Patterson et al., 2005). It is considered, though, that the authors' consensus on the difficulty of validating research 
instruments should not, however, discourage the initiative to do so; on the contrary, it justifies the intention of seeking contexts of culture and time within the applied survey.

Organizational climate surveys are empirical measurement tools that, since the 1930s, have aided the study of workplace conditions. Although their bases should be theoretically consolidated, the methods behind their construction should also consider the practical utility of the instrument in organizations and the professional universe to where it is applied.

These reasons led the authors of the present study to adopt three criteria for validation of the proposed category set: (1) the views of HR professionals and scholars; (2) the perceptions of the survey respondents; and (3) methods capable of demonstrating statistical consistency between the variables that compose the survey dimensions. We assume that the proposed categories Identity, Satisfaction and Motivation, Leadership, and Learning and Development - are not the only applicable ones, nor are they absolute or definitive choices for the measurement of organizational climate, but they did find some legitimacy when confronted with the aforementioned observation levels (theoretical, professional, and statistical).

The findings of this study intend to be suitable with Argyris (1960), who states that studies must create generalization and theory applicable to given types of organizations and to a given empirical case. Our concern with categories capable of measuring quality of the work environment reflects the need for attention to the generic applicability of organizational climate surveys.

Although all qualitative and quantitative assessments adopted in this study suggested that the proposed organizational climate categories are valid and consistent, there are a series of limitations that restrict the generalization of these results. The main limitation is the impossibility of including, in a discrete set of categories, the entire universe of relationships an individual may potentially encounter in the workplace. Another limitation concerns the diversity of factors that interfere with personal opinions of the work environment. Personal characteristics such as cultural level, gender, age, professional sector, and countless others certainly influence one's expectations as an employee; additionally, these variables were not monitored or even controlled, making it impractible to affirm any supposition concerning them.

Finally, we must note the limitations of our sample. Although its scope and size were unprecedented for an organizational behavior study conducted in Brazil, we are aware that 
statistical representativeness could not be ensured; our results must always be limited to the group that generated them.

In spite of these limitations, we consider that this study may contribute with those who are interested in improving the concept and practices of organizational climate surveys. Very recently The Academy of Management Journal promoted an interesting series of articles about the "Great Divide" between academics and pratictioners in Human Resouce Management (Rynes, 2007; Rynes, Giluk \& Brown, 2007; Lawler III, 2007; Cohen, 2007). The distance that the authors verify between the academy and the professional world in the U.S. and the U.K. is also true in Brazil. The group of researchers from which this paper was originated has the central preoccupation to generate a scientific production able to approximate both universes. We believe that the investigation practices adopted in this study, as the results found, can contribute with this objective, offering methodological and instrumental references that stimulate the critical reflection for academics and professionals.

It is expected that there was a contribution to confirm the pretext that the organizational climate surveys, as one of the most disseminate and recognized practices in HR, can only be legitimate if their content is aligned with three criteria: coherence with the basic theory on the theme, adequacy to the organizations' most pressing needs, and consistency with the stablished rules by the methodology adopted by the researcher (Schneider, 2000).

\section{REFERENCES}

Argyris, C. Personalidade e organização: o conflito entre o sistema e o indivíduo. Rio de Janeiro: USAID, 1957.

Argyris, C. Understanding Organizational Behavior. Homewood, Illinois: The Dorsey Press-Inc., 1960.

Arruda, M. C. C.; Whitaker, M. C.; Ramos, J. M. R. Fundamentos de Ética Empresarial e Econômica. São Paulo, Atlas, 2001.

Ashkanasy, N. M.; Wilderom, C. P. M. \& Peterson, M. F. Handbook of Organizational Culture and Climate. Thousand Oaks, California: Sage Publications, 2000. 
Bacharach, S. B. \& Bamberger, P. A. “9/11 and New York City Firefighters' Post Hoc Unit Support and Control Climates: A Context of Theory of the Consequences of Involvement in Traumatic Work-Related Events". Academy of Management Journal, 50(4), 849-868, 2007.

Bauman, Z. Identidade: interview given to Benedito Vecchi. Rio de Janeiro: Jorge Zahar Ed., 2005.

Bergamini, C. W. Motivação nas organizações. São Paulo: Atlas, 1997.

Casado, T. "A motivação e o trabalho". In Fleury, M.T.F. (ed.) As pessoas na organização. São Paulo, Editora Gente, 2002.

Coda, R. Pesquisa de clima organizacional: uma contribuição metodológica. Associate professorship thesis, University of São Paulo School of Economics, Business Administration and Accounting (FEA/USP), 1998.

Cohen, D. J. "The Very Separate Worlds of Academic and Practioner Periodicals in Human Resource Management: Reasons for the Divide and Concrete Solutions for Bridging the Gap". Academy of Management Journal, 50(5), 1013-1019, 2007.

Dedobbeleer, N. \& Beland, F. "Organizational Climate and Safety". In International Labour Organization. Available online at <http://www.ilo.org/encyclopedia/?doc\&nd= $857100073 \& \mathrm{nh}=0 \&$ ssect $=0>$. Retrieved on 21 April 2006.

Detert, J. R. \& Burris, E. R. "Leadership behavior and employee voice: is the door really open?". Academy of Management Journal, 50(4), 869-884, 2007.

Dutra, J. Competências: conceitos e instrumentos para a gestão de pessoas na empresa moderna. São Paulo: Atlas, 2004.

Eboli, E. "O desenvolvimento da pessoas e a educação corporativa". In FLEURY, M.T.F. (org.) As pessoas na organização. São Paulo, Editora Gente, 2002.

Eisenberger, R.; Huntington, R.; Hutchinson, S.; Sowa, D. "Perceived organizational support”. In Journal of Applied Psychology, 71, 500-507, 1986.

Fischer, A. L. “As decisões sobre o método dos diagnósticos organizacionais internos”. In CLADEA, 1996.

Fleury, M. T. L. \& Sampaio, J. "Uma discussão sobre cultura organizacional”. In As Pessoas na Organização. São Paulo: Editora Gente, 2002.

Franke, R. H. \& Kaul, J. D. "The Hawthorne Experiments: First Statistical Interpretation”. In American Sociological Review, 1978, vol. 43 (October): 624-643. 
Garvin, D. A. Building a learning organization. Harvard Business Review, p. 78-91, Jul/Aug, 1993.

Giddens, A. Modernidade e Identidade. Translated by Plínio Dentzien. Rio de Janeiro: Jorge Zahar Ed., 2002.

Gil, A.C. Métodos e Técnicas de Pesquisa Social. São Paulo: Atlas, 1994.

Glick, W. H. "Conceptualizing and measuring organizational and psychological climate: Pitfalls in multilevel research”. In Academy of Management Review, 10, 601-616, 1985.

Guia Exame e Você S/A. 150 melhores empresas para você trabalhar. São Paulo: Abril, 2006.

Guia Exame. Melhores e maiores. São Paulo: Abril, 2006.

Guion, R. "A note on organizational climate". In Organizational Behavior and Human Performance, 9: 120-125, 1973.

Hunter, L. W. \& Thatcher, S. M. B. "Feeling the heat: effects of stress, commitment, and job experience on job performance”. Academy of Management Journal, 50(4), 953-968, 2007.

James, L. \& Jones, A. "Organizational climate: A review of theory and Research". In Psychological Bulletin, 18: 1096-1112, 1974.

Katz, D. \& Kahn, R. L. The social psychology of organizations. New York: John Wiley, 1966.

Kerlinger, F. N. Foundations of Behavioral Research: Educational and Psychological Inquiry. New York: John Wiley, 1964.

Kolb, D.; Rubin, I. \& Mcintyre, J. Psicologia Organizacional. São Paulo: Atlas, 1978.

Krogh, G. Von; Ichijo, K. \& Nonaka, I. Facilitando a criação de conhecimento. Campus: Rio de Janeiro, 2001.

Lawler, E. E.; Hall, D. T. \& Oldham, G. R. "Organizational climate: Relationship to organizational structure, process, and performance". In Organizational Behavior and Human Performance, 11: 139-155, 1974.

Lawler, E. E. "Why HR Practices Are Not Evidence-Based". Academy of Management Journal, 50(5), 1033-1034, 2007.

Leitão, J. S. S.; Guimarães, T. A. \& Rosal, M. A. A. "Metodologia de diagnóstico de clima organizacional em ambiente de inovação tecnológica”. In Anais do EnANPAD, 1998.

Levek, A. R. H. C. \& Malschitzky, N. "Liderança". In: Faculdade São Francisco, Available online at <http://www.sfrancisco.edu.br/pdf/cap_humano/3.pdf>. Retrieved May 2006. 
Levering, R. Um excelente lugar para se trabalhar: o que torna alguns empregadores tão bons (e outros tão ruins). Rio de Janeiro: Qualitymark, 1986.

Lewin, K. Teoria dinâmica da personalidade. São Paulo: Cultrix, 1935.

Lewin, K. Teoria de campo em ciência social. São Paulo: Livraria Pioneira, 1951.

Lewin, K.; Lippitt, R. \& White, R. K. "Patterns of aggressive behavior in experimentally created social climates". In Journal of Social Psychology, 10, 271-299; 1939.

Likert, R. New patterns of management. New York: McGraw-Hill, 1961.

Limongi-França, A. C. \& Arellano, E. B. “Liderança, poder e comportamento organizacional”. In FLEURY, M.T.F. (ed.) As pessoas na organização. São Paulo, Editora Gente, 2002.

Meister, J. Educação Corporativa. São Paulo: Makron Books, 1999.

Mitchell, T. R. "An Evaluation of the Validity of Correlational Research Conducted in Organizations". In Academy of Management Review, 10(2), 192-205; 1985.

Morse, N. \& Reimer, E. “The experimental change of a major organizational variable”. In Journal of Abnormal and Social Psychology, 52, 120-129; 1956.

Nascimento, M. R.; Candatten, F. \& Maciel, C. O. "Intersecções entre clima e comprometimento organizacional: uma análise dos antecedentes, dimensionalidade e encontros entre construtos". In Anais do EnEO, 2004.

Nonaka, I. \& Takeuchi, H. Criação de conhecimento na empresa. Rio de Janeiro: Campus, 1997.

Oliveira, N. \& Moraes, L. F. R. "Clima organizacional: discussões metodológicas sobre a implantação de uma pesquisa no Banco do Brasil S/A”. In Anais do EnANPAD, 1999.

Oliveira, W. M. Perfil analítico-descritivo da pesquisa sobre clima organizacional em instituições de ensino superior: 1970-1995. Doctoral thesis, University of São Paulo School of Economics, Business Administration and Accounting (FEA/USP), 1996.

Patterson et al. "Validating the organizational climate measure: links to managerial practices, productivity and innovation”. In Journal of Organizational Behavior, 26: 379-408, 2005.

Payne, R. L.; Pugh, D. S. "Organizational structure and climate”. In M. D. Dunnette (ed.), Handbook of Industrial and Organizational Psychology. Chicago: Rand McNally, 1976.

Quinn, R. Beyond rational management. San Francisco: Jossey-Bass, 1988.

Pereira, J. C. R. Análise de dados qualitativos: estratégias metodológicas para as ciências da saúde, humanas e sociais. São Paulo: Editora da Universidade de São Paulo, 2001. 
Reichers, A. E.; Schneider, B. "Climate and Culture: An Evolution of Constructs". In B. Schneider (ed.), Organizational Climate and Culture, San Francisco: Jossey-Bass, 1990.

Richardson, R. J. et al. Pesquisa social: métodos e técnicas. São Paulo: Atlas, 1999.

Rogers, C. On Becoming a Person. Boston: Houghton Mifflin, 1961.

Rynes, S. L. "Editor's Forewood: Tackling the "Great Divide" between Research Production and Dissemination in Human Resource Management". Academy of Management Journal, 50(5), 985986, 2007.

Rynes, S. L.; Giluk, T. L. \& Brown, K. G. "The Very Separate Worlds of Academic and Practioner Periodicals in Human Resource Management: Implications for Evidence-Based Management". Academy of Management Journal, 50(5), 987-1008, 2007.

Sá, M. A. D.; Mendes, N. M. D.; Bispo, A. C. K. A.; Telmo, F. A.; Lacerda, S. C. G. \& Alves, C. A. "O espelho não tem duas faces: um estudo entre a cultura e o clima organizacional na UFPB". In Anais do EnANPAD, 2006.

Santos, N. M. B. F. \& Bedani, M. "Investigação e diagnóstico do clima organizacional: o desvendar na atividade turística". In Anais do EnEO, 2004.

Schein, E. H. Organizational culture and leadership: A dynamic view. San Francisco: JosseyBass, 1989.

Schneider, B. “Organizational climates: an essay”. In Personnel Psychology, 28, 447-479; 1975.

Schneider, B. \& Bartlett, C. J., "Individual differences and organizational climate, I: the research plan and questionnaire development”. In Personnel Psychology, Vol. 21, pp. 323-33, 1968.

Schneider, B.; Bowen, D. E.; Ehrhart, M. G. \& Holcombe, K. M. "Climate for service: evolution of a construct". In ASHKANASY, N. M.; WILDEROM, C. P. M. \& Peterson, M. F. Handbook of Organizational Culture and Climate. Thousand Oaks, California: Sage Publications, 21-36; 2000.

Schneider, B. \& Hall, D. T. "Correlates of Organizational Identification as a Function of Career Pattern and Organizational Type". In Administrative Science Quarterly, Vol. 17, No. 3, pp. 340350, Sep. 1972.

Schneider, B. \& Snyder, R. A. "Some relationships between job satisfaction and organizational climate”. Journal of Applied Psychology, 60: 318-328, 1975. 
Schneider, B. \& White, S. Service quality: research perspectives. Thousand Oaks, C.A. Sage Publications, 2004.

Selltiz, C. et al. Métodos de pesquisa nas relações sociais. $2^{\text {nd }}$ Brazilian ed. São Paulo: Editora E.P.U., 1987.

Senge, P. A quinta disciplina. São Paulo: Best Seller, 1990.

Tamayo, A.; Lima, D \& Silva, A. V. "Impacto do clima organizacional sobre o estresse no trabalho". In Anais do EnANPAD, 2002.

Teixeira, J. E. “Clima organizacional: empregados satisfeitos fazem bem aos negócios”. In Boog, G. \& Boog, M. (coord.) Manual de Gestão de pessoas e equipes. Volume 2. São Paulo: Editora Gente, 2002.

Woodman, R. W. \& King, D. C. "Organizational climate: science as folklore". In Academy of Management Review, Vol. 3, p. 816-26, 1978.

\footnotetext{
1 The relationship between organizational climate and financial outcomes is evident upon cross-referencing the results of "Guia 150 Melhores Empresas para Você Trabalhar, edição 2007" ("150 Best Companies to Work for" Guide, 2007 Edition) and "Guia 500 Melhores e Maiores, edição 2007 ("500 Best and Biggest" Guide, 2007 Edition)", both published by Editora Abril. Average return on equity (ROE) for the best companies to work for is $18.04 \%$, while the average for the "500 Best and Biggest" is $12.87 \%$.

${ }^{2}$ We used the ANPAD website search engine (http://www.anpad.org.br), which locates published works containing the search keyword in the title, abstract, and body text, for every event promoted by the association, and also those published in the RAC (Revista de Administração Contemporânea). Of the 25 located articles containing the term clima organizacional (Portuguese for organizational climate), only six carried it in the title (four published in the annals of EnANPAD - Encontro Nacional da ANPAD [National ANPAD Meeting], and two in the annals of EnEO Encontro Nacional de Estudos Organizacionais [National Meeting for Organizational Studies]) and, therefore, featured organizational climate as their main theme. The articles containing the expression in the body text alone merely mentioned it while discussing other subjects. The same search procedure was conducted at the AoM website, with the search expression being organizational climate; no article containing the expression in its title was published in the last ten years, and those that contained it in the body text, as those published by ANPAD, mostly concerned other themes.

${ }^{3}$ Companies that have been featured over six times in the yearly Guia "150 Melhores Empresas para Você Trabalhar" ("150 Best Companies to Work for" Guide), published by Editora Abril.
} 